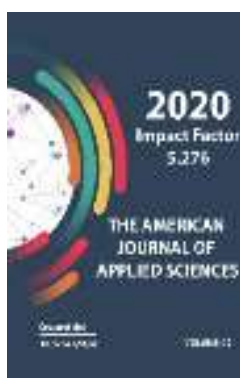

\title{
Shrines Of The Karshi Oasis
}

Sanabar Djuraeva

Candidate Of Historical Sciences, Doctoral Student (DSc) National University Of Uzbekistan

Journal Website:

http://usajournalshub.c

om/index,php/tajas

Copyright: Original content from this work

may be used under the

terms of the creative

commons attributes

4.0 licence.

\section{ABSTRACT}

The article describes the history of education, geographical location, as well as the role of Karshi oasis in the preservation of our cultural heritage and religious values.

\section{KEYWORDS}

Companions, saint scientist, Holy, place of pilgrimage, symbolic grave, Lords.

\section{INTRODUCTION}

The history of injection dates back a long time. Until the 14th century, the city was also called Balo, Nashibalo, Nakhshab, Nasaf. The city was located on a hill in ancient times, and the road from Bukhara to Samarkand passed through here [8:85]. The term Karshi has been used since the fourteenth century. The palace built by Kebekkhan, a Mongol from the Chigatay ulus, was called "Karshi" in Mongolian [8:85]. The ruins of the ancient city of Nakhshab are the present-day Shulliktepa monument, located northwest of Karshi [13: 4].

Amir Temur, who came to Movarounnahr and Khorasan squares in the $60 \mathrm{~s}$ of the 14th century, established his rule in Karshi and Shakhrisabz. During this period, the defensive wall of the Karshi fortress was reset. Sahibkiran spent the winter of 1385-1386 in Karshi [10: 441]. He built a large mosque in the center of 
the city fortress [6:40]. During this period, Karshi's prestige as a political, economic and cultural center increased.

\section{THE MAIN RESULTS AND FINDINGS}

Amir Temur was a scholar in the field of religion and memorized the Qur'an. For this reason, the respect for the saints in the Islamic world was very high. After conquering the land of Damascus (present-day Syria, Jordan, Lebanon, and Palestine) in 1401, the Companion visited the tomb of Abu Ubayda alJarrah in Jordan.

Abu Ubaydah al-Jarrah (? -639. Jordan (Jordan) was one of the Companions of the Prophet (peace and blessings of Allah be upon him) and one of the Ashshari Mubasharas. He was known in Islamic history as a brave and famous mujahideen, a great commander, and a just man. The original tomb was in the village of Amya, Jordan, on the west side of the Shari'a River. [3:28] In honor of him, he took soil from the tombs of Amir Temur and brought it to Nasaf, where he built the symbolic tomb and mausoleum of Abu Ubaydah al-Jarrah. ]. The shrine of Abu Ubayda al-Jarrah is now located on the southwest side of Karshi, on Jayhun Street in Gulshan neighbourhood.

The city, known as Karshi, and the surrounding area came to be known as the Karshi region. It is said in "Boburnoma": "They also say that I am from Karshi region, Nasaf and Nakhshab ... In Karshi region it is called Karshi in order to be happy and prosperous" [2:47]. In 1931, the Soviets established the Behbudi (Karshi) region in the Kashkadarya region. In 1938, due to another administrative-territorial change in the country, Kashkadarya region was abolished and included in Bukhara region. From this year Bekhbudi district is called Karshi district. In 1960, Kashkadarya region was included in Surkhandarya region, in 1963 it was separated from Surkhandarya region and became a separate region. Bishkent district, which was annexed to Kasan district in 1964, was renamed
Karshi district. Due to independence, Karshi district, which was called by different names during the Soviet era, was renamed Karshi district by the decision of the Council of People's Deputies of Kashkadarya region on March 13, 1992 (11R) [11:17].

Since the city of Karshi was formerly called Nakhshab, Nasaf, the great scholars who lived here were called Nakhshabi and Nasafi. There is a grave of such great scholars in Karshi district.

The village of Qovchin in the Karshi district is located $5 \mathrm{~km}$ from Bishkek. There are the blessed tombs of Abu Mu'in al-Nasafi (10271114), one of the disciples of Imam Abu Mansur al-Motrudi (870-944), one of the founders of theology [14:11]. He was considered one of the leading scholars of his time as an imam, a mutakkallim, a faqih, a hafiz, and a nahvi (grammar) [14: 6,12]. Abu Mu'in al-Nasafi's Tabsirat al-Adilla was of great scientific and practical importance and was the largest work of the scholar. In his book, he explained the basics of religion in the style of his teacher Abu Mansur al-Motrudi. For this reason, Abu Mu'in al-Nasafi was often known as Sahib at-Tabsira $[14: 22,23]$. Another valuable aspect of the work is that it contains important information about a number of scholars who worked in Movarounnahr at that time. The mausoleum of Khoja Shamsiddin Kholvoniy is located in the village of Qovchin, Karshi district. There is no information about this shrine except for the words "Khoja Shamsiddin Kholvani Sahibul Karomat, kofiful asror ..." on the tombstone [1:].

The village of Patron is located 15 kilometers southwest of Karshi, the regional center of Kashkadarya. In this village there is an ancient monument "Seven birth fathers" [11: 3]. There is the tomb of Saint Mirsaid Fatkhullah and his descendants Sayyidzoda (XVI-XVII centuries), which is connected with the genealogy of Hazrat Ali to the sons of Hassan and Hussein, 
The American Journal of Applied Sciences

(ISSN - 2689-0992)

Published: November 06, 2020 | Pages: 12-15

known in later centuries as the "Seven Fathers"

[9: 11,25].

In the ancient village of Nukrabad in the Karshi district, there is a symbolic tomb and shrine named after Hafiz Sherozi (1326-1389), one of the brightest stars of Persian literature [12: 125]. Sahibkiran Amir Temur met Hafiz Sherozi in 1387 when he went to conquer the Persian lands and the capital city Sheroz. He became acquainted with the work of the poet while studying at the Shakhrisabz madrasah. In 1393, Amir Temur recaptured Sheroz. He may have visited the tomb of Hafiz Shirazi. In 1410, the Persian lands were ruled by his grandson Pirmuhammad. His grandfather, Amir Temur, may have sent Hafiz Shirazi from his grave because of his respect for him. It is well known that Sahibkiran brought the lands of saints and great people from the conquered lands to the land of Turan.

The shrine of Sheikh Shibli is located in the village of Shilvi, southwest of Karshi, 12 kilometers from the center of Karshi district, Bishkent [12: 148]. Hazrat Shibli, whose full name is Abu Bakr Dulaf ibn Jahdar ibn Ja'far, was a Sufi from Baghdad, who, according to sources, was born around $861 \mathrm{AD}$ and died in 946. The term "Shibli" means "lion cub." He was the closest student of Junaid al-Baghdadi, as well as a student and schoolmate of Mansur Hallaj. Sheikh Abu Bakr Shibli's father was the chief hajib of the Caliph, and his uncle was Amir ul Umaro in Alexandria. Shibli himself served as the hajib of the caliph al-Muffaq [4: 21,22]. According to some scientific sources, in religious-legal (figh) and Qur'an sciences, the scholar Abu Bakr Shibli did not lag behind, or even surpassed, the most powerful scholars in this field. He was a mystical poet who wrote in Arabic. The tomb of Hazrat Abu Bakr Shibli in Baghdad has been preserved. It is still a place of pilgrimage today [4:22]. In the works of Fakhruddin Attor "Taskirat ul Awliyo", Alisher Navoi "Nasayim ul Muhabbat" the name of this great sheikh is mentioned with special respect.
The tomb of Sheikh Shibli in Karshi district is a symbolic tomb, which may have been brought by Sahibkiran Amir Temur.

\section{CONCLUSION}

In conclusion, it can be said that the Karshi oasis was inhabited by such great people as Abu Mu'in al-Nasafi, who was famous in the Islamic world. Their souls have found eternal abode here. Wherever Amir Temur walked, the scholars, religious scholars, companions and saints of those places paid their respects. For this reason, Abu Ubayda al-Jarrah in Karshi, Hafiz Shirazi, Sheikh Shibli and other scholars in Karshi district brought shrines and built shrines in his honor in our country.

At the same time, the graves of the grandsons of the Prophet (SAAS) Hassan and Husayn, whose genealogy goes back to ancient times, have been buried forever. One of the important tasks before us is to study the life and work of Islamic scholars, to pass on their scientific heritage to the next generation, to form the right worldview in the minds of young people, to increase the status of shrines in the Muslim world.

\section{REFERENCES}

1. Field Research Book 4. August 30, 2019.

2. Bobur Z.M. Boburnoma. T .: Yulduzcha Publishing House, 1990.

3. Encyclopedia of Islam. - T .: "National Encyclopedia of Uzbekistan" State Scientific Publishing House, 2017.

4. Ismail Khoji Raykhonov. The life and legacy of Hazrat Junayd al-Baghdadi. Karshi: Nasaf Publishing House, 2017.

5. Directory of the Department of Cultural Heritage of Kashkadarya region. Karshi, August 19, 2019.

6. Ismoilov N., Buriev O. Karshi is an ancient city of Uzbekistan. Karshi: Nasaf, 2006. 
7. Nosir Muhammad. School of skills: Amir.Temur-hafiz Sherozi. Samarkand, 2015. Information in the hands of the chief imam of Karshi district. Karshi district August 30, 2019.

8. Bo'riev O. Central Asia in the written sources of the Timurid period. - T .: Uzbekistan, 1997.

9. Ravshanov P, Uroqov R. The value of our ancestors. T: Sharq, 1999.

10. Ravshanov P. History of injection. - T .: Yangi asr avlodi, 2006.

11. Akbarov R., Shamsiddinov N. Seven flags family tree. T: "Tashkent Islamic University", 2015.

12. Akbarov R. History of Karshi district. "Tashkent Islamic University", 2016.

13. Po'latov S., Bo'taev A. Karshi is an ancient city. - Karshi: Nasaf, 2006.

14. Uvvatov U. Abul Mu'in al-Nasafi (Life and Legacy). T .: Spirituality, 2003.

15. National Encyclopedia of Uzbekistan. State Publishing House. T :: 2005, 10 vols.

16. Nurmatovna, D. S. (2020, October). Representatives of the" Khojagon" direction of the Naqshbandi sect. In Archive of Conferences (Vol. 7, No. 1, pp. 8-11).

17. Djuraeva, S. (2019). ZORAASTRISM AND ZOOLATRIC VIEWS AT THE MONUMENT JARQOTAN WHICH SITUATES AT THE SOUTH UZBEKISTAN. Theoretical \& Applied Science, (9), 166-168.

18. Djuraeva, S. (2019). SACRED PLACES IN SURKHAN OASIS AND POPULATION'S RELIGIOUS LIFE. Theoretical \& Applied Science, (7), 125-130.

19. Nurmatovna, D. S. (2020, October). Representatives of the" Khojagon" direction of the Naqshbandi sect. In Archive of Conferences (Vol. 7, No. 1, pp. 8-11).

20. Omonov, Q., \& Karimov, N. (2020). Importance Of Ancestoral Heritage. The American Journal of Social Science and Education Innovations, 2(09), 196202.

21. Karimov, N. R. (2020). A True Successor of Great Central Asian Scholars. Journal «Bulletin Social-Economic and Humanitarian Research,(7), 62-69.

22. Djuraeva, S. (2020). THE ROLE OF SPIRITUAL AND MATERIAL HERITAGE OF SURKHANDARYA REGION IN THE DEVELOPMENT OF TOURISM. Solid State Technology, 63(6), 290-296.

23. Kariev, A., \& Aminov, H. (2020). New information about Imam al-Zarnūjī and his work "Ta'lim al-Muta'allim". Solid State Technology, 63(6), 2372-2387.

24. Kurbanazarova N. Sh. (2020). Linguistic Study of some Uzbek Ethnographisms Expressing Wedding Ceremonies. International Journal of Psychosocial Rehabilitation, No.5, Pp. 3735-3740 